\title{
PENGARUH ORGANIZATIONAL CULTURE, SERVANT LEADERSHIP, DAN NON- PHYSICAL WORK ENVIRONMENT TERHADAP MOTIVASI DAN JOB PERFORMANCE
}

\author{
Gunarso Wiwoho \\ Email: gunarsowiwoho@gmail.com
}

\begin{abstract}
Abstrak
Penelitian ini bertujuan untuk menguji dan menganalisis pengaruh organizational culture, servant leadership dan non-physical work environment terhadap motivasi dan job performance pada pegawai Badan Pusat Statistik Kabupaten Kebumen. Pengumpulan data dilakukan dengan kuesioner dengan menggunakan skala likert 4 pilihan. Populasi dari penelitian ini yaitu jumlah seluruh pegawai yaitu 44 pegawai. Teknik pengambilan sampel dengan teknik sampling jenuh atau seluruh pegawai sebagai responden penelitian. Teknik analisis data menggunakan teknik analisis deskriptif dan statistik meliputi uji validitas, uji reliabilitas, uji asumsi klasik, uji hipotesis, analisis korelasi, dan analisis jalur (path analysis) dengan bantuan program SPSS for windows versi 23,0. Hasil dari penelitian ini yaitu organizational culture tidak berpengaruh terhadap motivasi. Servant leadership berpengaruh positif dan signifikan terhadap motivasi. Non-physical work environment berpengaruh secara positif dan signifikan terhadap motivasi. Organizational culture berpengaruh secara positif dan signifikan terhadap job performance. Servant leadership tidak berpengaruh terhadap job performance. Non-physical work environment tidak berpengaruh terhadap job performance, dan Motivasi berpengaruh secara positif dan signifikan terhadap job performance.
\end{abstract}

Kata kunci: Organizational culture, Servant leadership, Non-physical work environment, Motivasi dan job performance.

\begin{abstract}
This study aims to examine and analyze the influence of organizational culture, servant leadership and nonphysical work environment on motivation and job performance in employees of the Central Bureau of Statistics of Kebumen Regency. Data collection is done by questionnaire using a 4 Likert scale option. The population of this study is the total number of employees, namely 44 employees. Sampling techniques with saturated sampling techniques or all employees as research respondents. Data analysis techniques using descriptive analysis techniques and statistics include validity test, reliability test, classic assumption test, hypothesis test, correlation analysis, and path analysis (path analysis) with the help of SPSS for windows version 23.0. The results of this study namely organizational culture have no effect on motivation. Servant leadership has a positive and significant effect on motivation. Non-physical work environment has a positive and significant effect on motivation. Organizational culture has a positive and significant effect on job performance. Servant leadership does not affect job performance. Non-physical work environment does not affect job performance, and Motivation has a positive and significant effect on job performance. Keywords: Organizational culture, Servant leadership, Non-physical work environment, Motivation and job performance.
\end{abstract}

\section{PENDAHULUAN}

Organisasi baik itu swasta ataupun milik pemerintah akan berupaya dan berorientasi pada tujuan jangka panjang yaitu berkembangnya organisasi yang ditandai dengan semakin baiknya kinerja pegawai dalam organisasi tersebut. Pada saat ini instansi pemerintah dituntut untuk bekerja secara efektif dan efisien. Instansi pemerintah merupakan salah satu organisasi yang memiliki pegawai untuk dapat mengoperasikan organisasi tersebut. Seorang pegawai dapat dikatakan memiliki kinerja yang baik, apabila pegawai tersebut dapat menunjang tercapainya tujuan dan sasaran yang telah ditetapkan oleh organisasi.

Salah satu unsur terpenting yang dapat menentukan jalannya organisasi adalah sumber daya manusia. Pada dasarnya perusahaan tidak hanya mengharapkan sumber daya manusia yang cakap dan terampil, tetapi lebih penting lagi yaitu perusahaan mengharapkan pegawainya untuk bekerja dengan giat dan berkeinginan supaya mencapai hasil kerja yang optimal.

Menurut Mangkunegara (2009:9) Kinerja SDM adalah prestasi kerja atau hasil kerja (output) baik kualitas maupun kuantitas yang dicapai SDM persatuan periode waktu dalam melaksanakan tugas kerjanya sesuai dengan tanggung jawab yang diberikan kepadanya. Kinerja masing-masing pegawai ini yang nantinya akan membentuk sebuah kinerja dari organisasi itu sendiri.

Badan Pusat Statistik adalah Lembaga Pemerintahan Non Kementerian yang bertanggung jawab langsung kepada Presiden. Sebelumnya, BPS merupakan Biro Pusat 
Statistik, yang dibentuk berdasarkan UU Nomor 6 Tahun 1960 tentang sensus dan UU Nomor 7 tahun 1960 tentang statistik. Sebagai pengganti kedua UU tersebut ditetapkan UU Nomor 16 tahun 1997 tentang statistik. Berdasarkan UU ini yang ditindaklanjuti dengan peraturan perundangan dibawahnya, secara formal nama Biro Pusat Statistik diganti menjadi Badan Pusat Statistik. Peranan yang harus dijalankan BPS adalah menyediakan kebutuhan data bagi pemerintah dan masyarakat. Membantu kegiatan statistik di departemen, lembaga pemerintah atau institusi lainnya, dalam membangun sistem perstatistikan nasional. Mengembangkan dan mempromosikan standar teknik dan metodologi statistik, dan menyediakan pelayanan pada bidang pendidikan dan pelatihan statistik. Serta, membangun kerjasama dengan institusi internasional dan Negara lain untuk kepentingan perkembangan statistik Indonesia.

Badan Pusat Statistik Kabupaten Kebumen merupakan BPS yang bertanggungjawab menjalankan peran dalam skala kabupaten. BPS mempunyai tugas menyediakan data dan informasi statistik yang berkualitas, lengkap, akurat, mutakhir dan relevan bagi pengguna data. Jumlah pegawai Badan Pusat Statistik Kabupaten Kebumen berjumlah 44 pegawai. Secara umum BPS Kabupaten Kebumen telah memenuhi tugas dan fungsinya. Hal ini tercermin dari target yang telah dicapai pada tahun 2016 \& 2017. Ringkasan pencapaian masing-masing sasaran dapat dilihat pada tabel berikut ini:

Tabel 1. Pencapaian Kinerja 2016 \& 2017

\begin{tabular}{cccccc}
\hline \multirow{2}{*}{ No } & Indikator & \multicolumn{2}{c}{ Tahun 2016 } & \multicolumn{2}{c}{ Tahun 2017 } \\
\cline { 3 - 6 } & & $\begin{array}{c}\text { Tar } \\
\text { get }\end{array}$ & $\begin{array}{c}\text { Reali } \\
\text { sasi }\end{array}$ & $\begin{array}{c}\text { Tar } \\
\text { get }\end{array}$ & $\begin{array}{c}\text { Realisa } \\
\text { si }\end{array}$ \\
\hline 1 & Peningkatan & & & & \\
& kualitas data & 95 & 99,33 & 95 & $94,44 \%$ \\
& statistik & $\%$ & $\%$ & $\%$ & \\
& & & & & \\
& Peningkatan & & & & \\
& pelayanan & & & & \\
& prima hasil & 95 & & $98 \%$ & \\
& kegiatan & $\%$ & & $\%$ & \\
& statistik & & & &
\end{tabular}

3 Peningkatan

penyelenggara

an birokrasi

$\begin{array}{ccccc}\text { yang } & 60 & & 61 & \\ \text { akuntabel } & \% & 60 \% & \% & 57,63 \% \\ \text { Hasil } & \% & & & \end{array}$

penilaian

sakip oleh

inspektorat

Sumber: Laporan Akuntabilitas Kinerja Pegawai Badan Pusat Statistik Kabupaten Kebumen, 2016 \& 2017

Berdasarkan Tabel 1 dapat dijelaskan bahwa kinerja pegawai Badan Pusat Statistik Kabupaten Kebumen pada tahun 2017 kurang maksimal ditandai dengan belum tercapainya keseluruhan target indikator. Hasil tersebut tidak semaksimal tahun sebelumnya, dimana masing- masing indikator penilaian kinerja sudah tercapai secara maksimal. Hasil kinerja dengan tujuan peningkatan kualitas data yang kurang maksimal tersebut mengakibatkan penilaian oleh inspektorat juga turun. Kurang maksimalnya pencapian tersebut dikarenakan target response rate survei dengan pendekatan rumah tangga, usaha dan non-rumah tangga, non-usaha, lebih kecil dari target.

Job performance (kinerja) menurut Donnely, Gibson, dan Ivancevich yang dikutip oleh Rivai (2005:15) dinilai sebagai tingkat keberhasilan dalam melaksanakan tugas serta kemampuan untuk mencapai tujuan yang telah ditetapkan. Berdasarkan hasil wawancara pada Kepala Subbagian Tata Usaha BPS Kabupaten Kebumen penilaian kinerja pegawai dipantau untuk terciptanya kualitas kinerja yang lebih baik. Penyelesaian tugas seharusnya secara efektif dan efisien serta melakukan peran dan fungsinya yang berhubungan positif bagi keberhasilan suatu badan penyedia data. Berdasarkan jumlah hasil kerja setiap tahunnya BPS mampu menyelesaikan seluruh rangkaian survei dalam satu tahun, dan sensus yang dilakukan setiap 10 tahun sekali, rinciannya ialah pada tahun dengan akhiran angka 3 merupakan sensus pertanian, tahun dengan akhir angka 6 yaitu sensus ekonomi, dan tahun dengan akhiran 0 yaitu sensus penduduk. BPS belum sepenuhnya berhasil mendapatkan data berkualitas yang dibutuhkan oleh pemerintah pusat dan daerah serta masyarakat yang berkepentingan.

Proses sensus dan survei tersebut dipantau secara langsung oleh pemimpin untuk memastikan pengambilan data sesuai dengan kondisi yang ada dilapangan. Pegawai menguasai bagian dalam proses sensus, pegawai bekerja sesuai dengan perintah pemimpin, akan tetapi mereka juga memiliki inisiatif memecahkan masalah pada saat terjadi kendala. Pegawai pada BPS dituntut untuk sering melakukan kegiatan secara teamwork, sehingga pegawai sangat memperhatikan

kehadiran demi berjalannya

teamwork tersebut dengan baik. Pegawai harus siap dengan kondisi dikantor dan lapangan untuk melakukan sensus dan survei. Hasil kerja tersebut juga dipengaruhi oleh kualitas dari masing-masing pegawai secara individu. Berbagai hal dapat mempengaruhi kinerja yang dimiliki oleh pegawai, seperti organizational culture (budaya organisasi), servant leadership (pemimpin yang melayani),

non-physical dan

environment (lingkungan kerja non-fisik) yang terdapat dalam BPS Kabupaten Kebumen.

Setiap perusahaan tentunya menginginkan agar pegawai dalam organisasi selalu memiliki motivasi dalam mengerjakan tugas-tugasnya. Motivasi tersebut diharapkan berpengaruh secara positif yang nantinya akan mempengaruhi kinerja yang baik pula. Berdasarkan faktor-faktor yang mempengaruhi kinerja seperti organizational culture, servant leadership, dan non-physical work environment, pegawai diharapkan akan lebih termotivasi untuk mendapatkan kinerja yang optimal, efektif dan efisien sesuai dengan yang diharapkan organisasi. Pegawai perlu diberikan perhatian yang lebih terhadap tugas yang diberikan pada masing- masing pegawai demi tercapainya tujuan organisasi. Dengan motivasi yang tinggi pegawai diharapkan akan bekerja lebih giat dalam menyelesaikan tugas-tugas 
yang menjadi tanggung jawabnya. Sebaliknya, apabila motivasi pegawai rendah, pegawai tidak memiliki semangat kerja, mudah mengeluh dengan setiap kendala yang muncul, dan sulit menyelesaikan tugasnya dengan baik. Hal ini yang dikhawatirkan akan menghambat kinerja dan pencapaian tujuan organisasi secara optimal.

Berdasarkan uraian diatas, maka peneliti tertarik untuk melakukan penelitian dengan judul "PENGARUH ORGANIZATIONAL CULTURE, SERVANT LEADERSHIP DAN NON-PHYSICAL WORK ENVIRONMENT TERHADAP MOTIVASI DAN JOB PERFORMANCE".

Rumusan Masalah

Rumusan masalah dalam penelitian ini adalah:

"Bagaimanakah pengaruh organizational culture, servant leadership dan non-physical work environment terhadap motivasi dan job performance pada Pegawai Badan Pusat Statistik Kabupaten Kebumen”.

\section{Tujuan Penelitian}

Tujuan dalam penelitian ini adalah:

1. Untuk mengetahui pengaruh organizational culture terhadap job performance pada pegawai Badan Pusat Statistik Kabupaten Kebumen.

2. Untuk mengetahui pengaruh servant leadership terhadap job performance pada pegawai Badan Pusat Statistik Kabupaten Kebumen.

3. Untuk mengetahui pengaruh non-physical work environment terhadap job performance pada pegawai Badan Pusat Statistik Kabupaten Kebumen.

4. Untuk mengetahui pengaruh organizational culture terhadap motivasi pada pegawai Badan Pusat Statistik Kabupaten Kebumen.

5. Untuk mengetahui pengaruh servant leadership terhadap motivasi pada pegawai Badan Pusat Statistik Kabupaten Kebumen.

6. Untuk mengetahui pengaruh non-physical work environment terhadap motivasi pada pegawai Badan Pusat Statistik Kabupaten Kebumen.

7. Untuk mengetahui pengaruh motivasi terhadap job performance pada pegawai Badan Pusat Statistik Kabupaten Kebumen.

TINJAUAN PUSTAKA

Job Performance

Menurut Mangkunegara (2011:67) kinerja adalah hasil kerja secara kualitas dan kuantitas yang dicapai oleh seseorang karyawan dalam melaksanakan tugasnya sesuai dengan tanggung jawab yang diberikan kepadanya.

Menurut Bernadin dan Russel dalam Gomes Lardoso Faustino (2010:142), standar pengukuran kinerja diantarnya sebagai berikut:

1) Quantity of work

2) Quality of work

3) Job knowledge

4) Creativeness

5) Cooperative

6) Dependability

7) Initiative

8) Personal qualities

Organizational Culture
Budaya organisasi mengacu kesistem makna bersama yang di anut oleh anggota-anggota yang membedakan organisasi itu dari organisasi yang lain. Sistem makna bersama ini bila diamati dengan seksama, merupakan seperangkat karakteristik utama yang dihargai oleh organisasi itu, Robbins (2006:721).

Penilaian organizational culture dalam penelitian ini dibatasi pada Robbins (2006):

1) Inovasi dan keberanian mengambil resiko

2) Perhatian terhadap detail

3) Berorientasi kepada hasil

4) Berorientasi kepada orang

5) Berorientasi tim

6) Agresif

7) Stabil

\section{Servant Leadership}

Menurut Trompenaars dan Voerman (2010:3), servant leadership adalah gaya manajemen dalam hal memimpin dan melayani berada dalam satu harmoni, dan terdapat interaksi dengan lingkungan. Seorang servant leadership adalah seseorang yang memiliki keinginan kuat untuk melayani dan memimpin, dan yang penting adalah mampu menggabungkan keduanya sebagai hal saling memperkuat secara positif.

Penilaian servant leadership pada penelitian ini dibatasi pada Dennis (2004):

1) Kasih sayang (love)

2) Pemberdayaan (empowerment)

3) Visi (vision)

4) Kerendahan hati (humility)

5) Kepercayaan (trust)

Non-physical work environment

Sedarmayanti (2009:31) mengemukakan bahwa nonphysical work environment adalah semua keadaan yang terjadi yang berkaitan dengan hubungan kerja, baik hubungan dengan atasan maupun dengan sesama rekan kerja, ataupun hubungan dengan bawahan.

Non-physical work environment pada penelitian ini dibatasi pada Sedarmayanti (2009:31):

1) Hubungan kerja antara bawahan dengan atasan.

2) Hubungan kerja antara sesama pegawai.

\section{Motivasi}

Hasibuan (2002:141) menyatakan bahwa motivasi adalah daya penggerak yang menciptakan kegairahan kerja seseorang agar mereka mau bekerja efektif dan terorganisasi dengans segala upayanya untuk mencapai kepuasan.

Motivasi pada penelitian ini dibatasi pada Herzberg dalam Hasibuan (2003:109-110):

1) Prestasi (achievement)

2) Pengakuan (recognition)

3) Pekerjaan itu sendiri (work it self)

4) Tanggung jawab (responsibility)

5) Pengembangan potensi diri (advancement)

\section{MODEL EMPIRIS}

Berdasarkan tinjauan teori dan telaah penelitian terdahulu, dapat digambarkan model empiris "Pengaruh Organizational Culture, Servant Leadership dan Non- 
physical Work Environment terhadap Motivasi dan Job Performance" sebagai berikut:

Gambar 1. Model Empiris

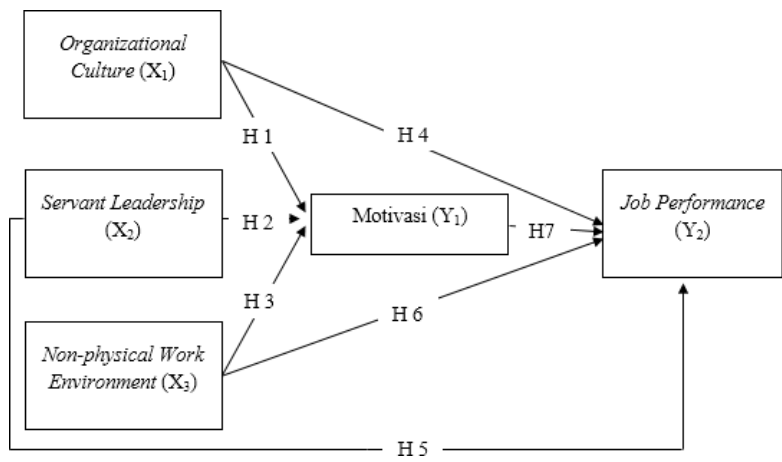

Berdasarkan latar belakang masalah, perumusan masalah, tujuan masalah dan landasan teori sebagaimana yang telah disebutkan sebelumnya maka hipotesisnya atau dugaan sementara yang diajukan dalam penelitiian ini adalah sebagai berikut:

H1= Diduga organizational culture berpengaruh terhadap motivasi pada pegawai Badan Pusat Statistik Kabupaten Kebumen.

H2= Diduga servant leadership berpengaruh terhadap motivasi pada pegawai Badan Pusat Statistik Kabupaten Kebumen.

H3= Diduga non-physical work environment berpengaruh terhadap motivasi pada pegawai Badan Pusat Statistik Kabupaten Kebumen.

H4= Diduga organizational culture berpengaruh terhadap job performance pada pegawai Badan Pusat Statistik Kabupaten Kebumen.

H5= Diduga servant leadership berpengaruh terhadap job performance pada pegawai Badan Pusat Statistik Kabupaten Kebumen.

H6= Diduga non-physical work environment terhadap job performance pada pegawai Badan Pusat Statistik Kabupaten Kebumen.

H7 = Diduga Motivasi berpengaruh terhadap job performance pada pegawai Badan Pusat Statistik Kabupaten Kebumen.

\section{METODE}

Obyek penelitian ini adalah variabel organizational culture, servant leadership, non-physical work environment, motivasi dan job performance. Subyek penelitian ini adalah pegawai Badan Pusat Statistik Kabupaten Kebumen yang berjumlah 44 (empat puluh empat) pegawai. Penelitian ini menggunakan pengambilan sampel dengan teknik sampling jenuh karena populasinya kurang dari 100 pegawai, maka teknik sampling yang diambil adalah semua anggota populasi atau semua pegawai Badan Pusat Statistik Kabupaten Kebumen yang berjumlah 44 pegawai. Metode dalam penelitian ini menggunakan observasi, wawanara, kuesioner, dan studi Pustaka.

Instrumen atau alat pengumpulan data dalam penelitian ini dilakukan dengan menggunakan kuesioner yang ditunjukan untuk memperoleh jawaban dari responden. Alat bantu pengolahan data menggunakan
SPSS 23 for windows (Statistical Product and Services Solutions).

Teknik analisis data dilakukan dengan dua cara yaitu analisis deskriptif dan anlisis statistika. Analisis deskriptif meliputi: (1) Responden berdasarkan jenis kelamin; (2) Responden berdasarkan usia; (3) Responden berdasarkan pekerjaan; (4) responden berdasarkan lama penggunaan. Analisis data secara statistika meliputi: (1) uji validitas dan reliabilitas; (2) uji asumsi klasik; (3) uji hipotesis; (4) analisis korelasi; (5) analisis jalur.

\section{HASIL DAN PEMBAHASAN \\ Uji Validitas}

Uji validitas digunakan untuk sah atau valid tidaknya suatu kuisioner. Alat ukur yang dapat digunakan dalam pengujian validitas suatu angket atau kuisioner adalah angka hasil korelasi antar skor angket dengan skor keseluruhan responden terhadap informasi dalam kuisioner. Menurut Ghozali (2006:50) dasar pengambilan keputusan sebagai berikut:

a. Jika $r$ hitung positif, serta $r_{\text {hasil }}>r_{\text {tabel }}$, maka variabel tersebut dinyatakan valid.

b. Jika $r$ hitung negatif, serta $r_{\text {hasil }}<r_{\text {tabel }}$, maka variabel tersebut dinyatakan tidak valid.

Nilai $\mathrm{r}_{\text {tabel }}$ dengan tingkat signifikansi 5\%=0,05 dan $\mathrm{df}=$ $\mathrm{N}-2$ dalam penelitian ini $\mathrm{df}=44-2=42$ ditemukan $\mathrm{r}$ tabel sebesar 0,2973.

Berikut peneliti sajikan uji validitas untuk kuisioner yang diberikan kepada responden dalam bentuk tabel sebagai berikut:

Tabel 2. Hasil Uji Validitas Organizational Culture

\begin{tabular}{lcccc}
\hline Butir & $\boldsymbol{r}_{\text {hitung }}$ & $\boldsymbol{r}_{\text {tabel }}$ & Sig. & Keterangan \\
\hline 1. & 0,758 & 0,2973 & 0,000 & Valid \\
2. & 0,739 & 0,2973 & 0,000 & Valid \\
3. & 0,675 & 0,2973 & 0,000 & Valid \\
4. & 0,598 & 0,2973 & 0,000 & Valid \\
5. & 0,584 & 0,2973 & 0,000 & Valid \\
6. & 0,347 & 0,2973 & 0,021 & Valid \\
7. & $\underline{0,636}$ & $\underline{0,2973}$ & $\underline{0,000}$ & Valid \\
\hline
\end{tabular}

Sumber: Data primer diolah, 2019

Tabel 3. Hasil Uji Validitas Servant Leadership

\begin{tabular}{|c|c|c|c|c|}
\hline Butir & r hitung & r tabel & sig. & keterangan \\
\hline 1 & 0,773 & 0,2973 & 0,000 & Valid \\
\hline 2 & 0,777 & 0,2973 & 0,000 & Valid \\
\hline 3 & 0,655 & 0,2973 & 0,000 & Valid \\
\hline 4 & 0,640 & 0,2973 & 0,000 & Valid \\
\hline 5 & 0,587 & 0,2973 & 0,000 & Valid \\
\hline
\end{tabular}

Sumber: Data primer diolah, 2019

Tabel 4. Hasil Uji Validitas Non-Physical Work Environment

\begin{tabular}{|c|c|c|c|c|}
\hline Butir & r hitung & $r$ tabel & sig. & keterangan \\
\hline 1 & 0,833 & 0,2973 & 0,000 & Valid \\
\hline 2 & 0,808 & 0,2973 & 0,000 & Valid \\
\hline 3 & 0,370 & 0,2973 & 0,013 & Valid \\
\hline 4 & 0,580 & $\underline{0,2973}$ & $\underline{0,000}$ & Valid \\
\hline
\end{tabular}

Sumber: Data primer diolah, 2019 
Tabel 5. Hasil Uji Validitas Motivasi

\begin{tabular}{|c|c|c|c|c|}
\hline Butir & r hitung & r tabel & sig. & keterangan \\
\hline 1 & 0,718 & 0,2973 & 0,000 & Valid \\
\hline 2 & 0,605 & 0,2973 & 0,000 & Valid \\
\hline 3 & 0,644 & 0,2973 & 0,000 & Valid \\
\hline 4 & 0,734 & 0,2973 & 0,000 & Valid \\
\hline 5 & 0,730 & 0,2973 & 0,000 & Valid \\
\hline \multicolumn{5}{|c|}{ Sumber: Data primer diolah, 2019} \\
\hline \multicolumn{5}{|c|}{ Tabel 6. Hasil Uji Validitas Organizational Culture } \\
\hline Butir & $\boldsymbol{r}_{\text {hitung }}$ & $r_{\text {tabel }}$ & Sig. & Keterangan \\
\hline 1. & 0,595 & 0,2973 & 0,000 & Valid \\
\hline 2. & 0,569 & 0,2973 & 0,000 & Valid \\
\hline 3. & 0,445 & 0,2973 & 0,002 & Valid \\
\hline 4. & 0,473 & 0,2973 & 0,001 & Valid \\
\hline 5. & 0,633 & 0,2973 & 0,000 & Valid \\
\hline 6. & 0,581 & 0,2973 & 0,000 & Valid \\
\hline 7. & 0,712 & 0,2973 & 0,000 & Valid \\
\hline 8. & 0,542 & 0,2973 & $\underline{0,000}$ & Valid \\
\hline
\end{tabular}

Sumber: Data primer diolah, 2019

Berdasarkan tabel uji vailiditas di atas, seluruh butir pernyataan memiliki $r_{\text {hitung }}>r_{\text {tabel}}$, dan tingkat signifikansi $<0,05$, sehingga dapat dijelaskan bahwa seluruh item pada tiap variabel dinyatakan valid.

\section{Uji Reliabilitas}

Uji reliabilitas dilakukan untuk melihat kestabilan dan konsistensi dalam menjawab hal yang berkaitan dengan pertanyaan atau pernyataan dalam suatu bentuk angket. Hasil uji ini akan mencerminkan dapat atau tidaknya suatu instrument penelitian dipercaya, berdasarkan tingkat ketepatan dan kemantapan suatu alat ukur. Reliabilitas dalam penelitian ini diuji dengan menggunakan hasil Cronbach Alpha, dengan ketentuan apabila nilai Cronbach Alpha > 0,60 atau 60\% maka instrument pengukuran reliabel, (Ghozali, 2009). Masing-masing variabel yangditeliti menunjukkan nilai Cronbach Alpha >0,60, sehingga dapat dijelaskan bahwa seluruh item pernyataan dari masing-masing variabel adalah reliabel. Hasil uji reliabilitas penulis sajikan dalam tabel berikut:

Tabel 7. Hasil Uji Reliabilitas

\begin{tabular}{ccc} 
Variabel & $\begin{array}{c}\text { Cronbach } \\
\text { Alpha }\end{array}$ & $\begin{array}{c}\text { Keteran } \\
\text { gan }\end{array}$ \\
\hline Organizational Culture $\left(\mathbf{X}_{1}\right)$ & 0,716 & Reliabel \\
Servant Leadership $\left(\mathbf{X}_{2}\right)$ & 0,713 & Reliabel \\
Non-physical Work & 0,611 & Reliabel \\
Environment $\left(\mathbf{X}_{3}\right)$ & & \\
Motivasi $\left(\mathbf{Y}_{1}\right)$ & 0,721 & Reliabel \\
Job Performance $\left(\mathbf{Y}_{2}\right)$ & 0,707 & Reliabel \\
\hline
\end{tabular}

Sumber: Data primer diolah, 2019

\section{Uji Multikolinieritas}

Uji multikolinearitas menurut Ghozali (2009:95) bertujuan untuk menguji apakah model regresi ditemukan adanya korelasi antar variabel bebas (independen). Model regresi yang baik seharusnya tidak terjadi korelasi di antara variabel independen.
Tabel 8. Uji Multikolinearitas Sub Struktural I Coefficients $^{a}$

\begin{tabular}{|c|c|c|c|}
\hline \multirow[b]{2}{*}{ Model } & & \multicolumn{2}{|c|}{ Collinearity Statistic } \\
\hline & & Tolerance & VIF \\
\hline \multirow[t]{4}{*}{1} & (Constant) & & \\
\hline & $\begin{array}{c}\text { Organizational } \\
\text { Culture }\end{array}$ & .658 & 1.519 \\
\hline & $\begin{array}{c}\text { Servant } \\
\text { Leadership }\end{array}$ & .766 & 1.306 \\
\hline & $\begin{array}{l}\text { Nonphysical } \\
\text { work } \\
\text { environment }\end{array}$ & .772 & 1.296 \\
\hline
\end{tabular}

a. Dependent Variable: Motivasi

Tabel 9. Uji Multikolinearitas Sub Struktural II Coefficients $^{\mathrm{a}}$

\begin{tabular}{|c|c|c|c|}
\hline \multirow[b]{2}{*}{ Model } & & \multicolumn{2}{|c|}{ Collinearity Statistic } \\
\hline & & Tolerance & VIF \\
\hline \multirow[t]{5}{*}{1} & (Constant) & & \\
\hline & Organizational Culture & .637 & 1.570 \\
\hline & Servant Leadership & .578 & 1.126 \\
\hline & Nonphysical work & .687 & 1.455 \\
\hline & Motivasi & 639 & 1.565 \\
\hline
\end{tabular}

a. Dependent Variable: Job Performance

Sumber: Data primer diolah, 2019

Berdasarkan tabel hasil uji multikolinearitas model 1 dan model 2, dapat diketahui bahwa nilai tolerance diatas 0,10 dan VIF dibawah angka 10 sehingga model regresi tidak terjadi multikolinearitas.

\section{Uji Heteroskedastisitas}

Uji heterokedastisitas bertujuan menguji apakah dalam model regresi terjadi ketidaksamaan variance dari residual satu pengamatan ke pengamatan yang lain, Ghozali (2009: 125).

a. Berdasarkan Uji Scatterplot

Dasar analisis atau dasar untuk mendeteksi ada atau tidaknya heterokedastisitas (varians yang berbeda) adalah dengan media grafik sebagai berikut:

Gambar 2. Uji Scatterplot Sub Struktural I




Gambar 3. Uji Scatterplot Sub Struktural II

Scatterplot

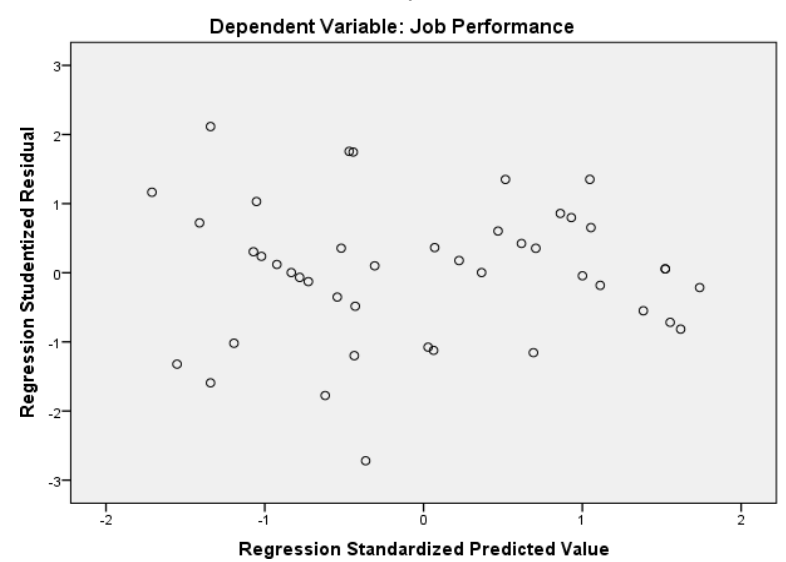

Berdasarkan gambar scatterplots sub struktural I dan II terlihat bahwa tidak ada pola tertentu seperti titik-titik yang membentuk suatu pola tertentu yang teratur (melebar, menyempit), tidak terdapat pola yang jelas sehingga dapat disimpulkan bahwa model regresi pada penelitian ini tidak terjadi heterokedastisitas.

b. Uji Glejser

Pada uji glejser menurut Ghozali (2009:129), jika variabel independen signifikan secara statistik mempengaruhi variabel dependen, maka ada indikasi terjadi heterokedastisitas.

Tabel 10. Hasil Uji Glejser Sub Struktural I Coefficients $^{a}$

\begin{tabular}{lcl}
\multicolumn{1}{c}{ Model $_{1}$} & Coefficients $^{\mathbf{a}}$ & Sig. \\
& (constant) & .113 \\
& Organizational Culture & .440 \\
& Servant Leadership & .986 \\
& Nonphysical Work Environment & .775 \\
\hline
\end{tabular}

a. Dependent Variable: RES1

Sumber: Data primer diolah, 2019

Tabel 11. Hasil Uji Glejser Sub Struktural I Coefficients $^{a}$

\begin{tabular}{lcc}
\hline Model & (constant) & Sig. \\
\hline $\mathbf{1}$ & Organizational Culture & .012 \\
& Servant Leadership & .700 \\
& Nonphysical Work Environment & .171 \\
& Motivasi & .647 \\
& & .949
\end{tabular}

a. Dependent Variable: RES2

Sumber: Data primer diolah, 2019

Hasil tampilan output SPSS hasil uji glejser model di atas dengan jelas menunjukkan bahwa tidak ada satupun variabel independen yang signifikan secara statistik, terlihat dari tingkat signifikan > 0,05 jadi dapat disimpulkan model regresi tidak terjadi heterokedastisitas. Hal ini sesuai dengan hasil uji scatterplot.

\section{Uji Normalitas}

Uji normalitas menurut Ghozali (2009: 147) bertujuan untuk menguji apakah dalam model regresi kedua variabel dependen maupun independen mempunyai distribusi normal ataukah tidak. Model regresi yang baik adalah memiliki distribusi data normal. a. Berdasarkan analisis grafik (Normal P-P Plot of Regression Residual)

Adapun untuk menguji dilakukan dengan analisis grafik, yaitu dengan melihat normal probability plot. Jika model regresi memenuhi asumsi normalitas, maka pada grafik normal plot distribusi normal. Jika model regresi tidak memenuhi asumsi normalitas, maka pada grafik normal plot, data atau titik menyebar jauh dari garis diagonal dan atau tidak mengikuti arah garis diagonal. Hasil uji normalitas disajikan pada Gambar berikut:

Gambar 4. Hasil Uji Normalitas Model 1

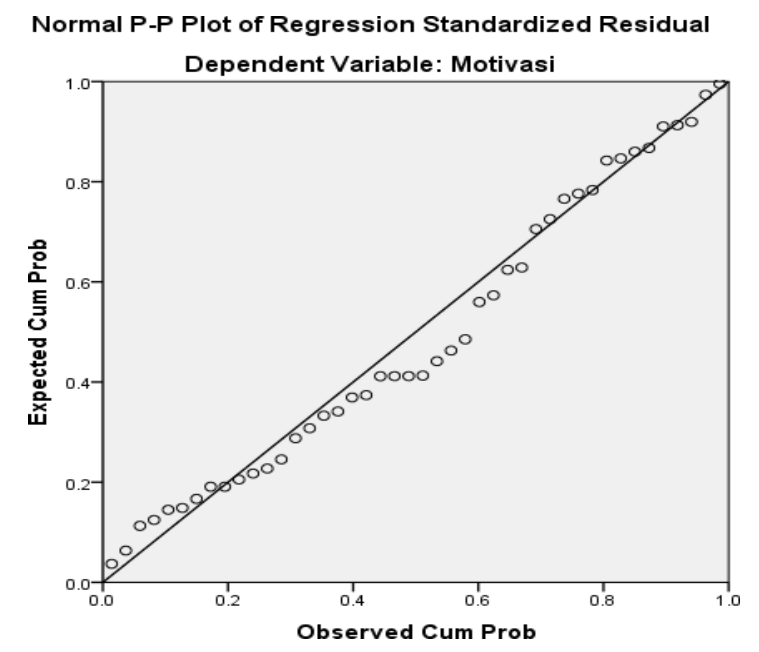

Sumber: Data primer diolah, 2019

Gambar 4. Hasil Uji Normalitas Model 2

Normal P-P Plot of Regression Standardized Residual

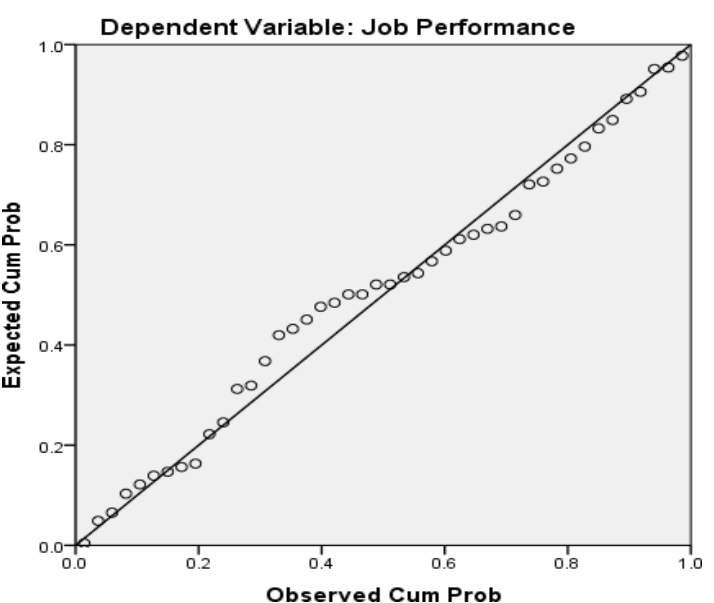

Sumber: Data primer diolah, 2019

Berdasarkan gambar hasil uji normalitas diatas (Normal P-P Plot of Regression Residual) diketahui bahwa titik-titik menyebar disekitar garis diagonal dan mengikuti arah garis diagonal, maka model regresi tersebut memenuhi asumsi normalitas.

b. Berdasarkan Uji Kolmogorov-Smirnov

Dasar pengambilan dalam uji normalitas K-S, jika nilai signifikansi lebih besar dari 0,05 maka data penelitian berdistribusi normal, dan sebaliknya. 
Tabel 12. Hasil Uji Kolmogorov Smirnov Model 1 One-Sample Kolmogorov-Smirnov Test

\begin{tabular}{|ll|r|}
\hline & & $\begin{array}{r}\text { Unstandardiz } \\
\text { ed Residual }\end{array}$ \\
\hline $\mathrm{N}$ & Mean & 44 \\
Normal Parameters & .0000000 \\
& Std. & 1.29543191 \\
& Deviation & .113 \\
Most Extreme Differences & Absolute & .113 \\
& Positive & -.059 \\
& Negative & .113 \\
Test Statistic & & $.192^{c}$ \\
Asymp. Sig. (2-tailed) & & \\
\hline
\end{tabular}

a. Test distribution is Normal.

b. Calculated from data.

c. Lilliefors Significance Correction.

Tabel 13. Hasil Uji Kolmogorov Smirnov Model 2

One-Sample Kolmogorov-Smirnov Test

\begin{tabular}{|ll|r|}
\hline & & $\begin{array}{r}\text { Unstandardiz } \\
\text { ed Residual }\end{array}$ \\
\hline $\mathrm{N}$ & Mean & 44 \\
Normal Parameters & .0000000 \\
& Std. & 1.35304149 \\
& Deviation & .098 \\
Most Extreme Differences & Absolute & .061 \\
& Positive & -.098 \\
& Negative & .098 \\
Test Statistic & & $.200^{\mathrm{c}, \mathrm{d}}$ \\
\hline
\end{tabular}

a. Test distribution is Normal.

b. Calculated from data.

c. Lilliefors Significance Correction

d. This is a lower bound of the true significance.

Sumber: Data primer diolah, 2019

Berdasarkan tabel hasil uji kolmogorov smirnov model 1 dan 2 output SPSS tersebut, diketahui bahwa nilai signifikansi Asymp. Sig. (2-tailed) sebesar 0,200 > 0,05. Sesuai dengan hasil tersebut dapat disimpulkan bahwa data berdistribusi normal. Hal tersebut sesuai dengan hasil uji grafik (Normal P-P Plot of Regression Residual).

\section{Uji Hipotesis}

Uji Hipotesis Parsial (Uji t)

Uji parsial (Uji t) dalam penelitian ini dimaksudkan untuk mengetahui pengaruh secara parsial variabel organizational culture, servant leadership dan nonphysical work environment terhadap motivasi dan job performance. Ketentuan pengujian, tingkat signifikansi sebesar $5 \%$ atau 0,05 , dengan tingkat keyakinan $95 \%$ atau 0,950. Pedoman penarikan kesimpulan jika nilai signifikansi $<0,05$ dan $\mathrm{t}$ hitung $>\mathrm{t}$ tabel. Penentuan $\mathrm{t}$ tabel dengan rumus $\mathrm{df}=\mathrm{n}-\mathrm{k}$.

\section{a. Pengujian Model 1}

$\mathrm{t}$ tabel dalam pengujian model 1 yaitu, $\mathrm{df}=44-3=41$ nilai $\mathrm{t}$ tabel sebesar 2,0195.
Tabel 14. Hasil Uji Hipotesis Sub Struktural I

\begin{tabular}{|c|c|c|c|c|c|}
\hline & $\begin{array}{l}\text { Unsta } \\
\text { Coef }\end{array}$ & $\begin{array}{l}\text { ndardi } \\
\text { ed } \\
\text { icients } \\
\text { Std. }\end{array}$ & $\begin{array}{c}\text { Standardiz } \\
\text { ed } \\
\text { Coefficients }\end{array}$ & & Sig \\
\hline Model & B & Error & Beta & $\mathbf{t}$ & . \\
\hline 1. (constant) & 4.101 & 2.853 & & 1.438 & .158 \\
\hline $\begin{array}{l}\text { Organizationa } \\
\text { I Culture }\end{array}$ & -.126 & .108 & -.181 & -1.161 & .253 \\
\hline $\begin{array}{c}\text { Servant } \\
\text { Leadership }\end{array}$ & .524 & .146 & .518 & 3.588 & .001 \\
\hline $\begin{array}{l}\text { Nonphysical } \\
\text { Work } \\
\text { Environment }\end{array}$ & .478 & .215 & .320 & 2.221 & .032 \\
\hline
\end{tabular}

Sumber: Data primer diolah, 2019

1) Hubungan antara Organizational culture dan Motivasi

Nilai $\mathrm{t}$ hitung variabel organizational culture $\left(\mathrm{X}_{1}\right)$ sebesar $-1,161<\mathrm{t}$ tabel 2,0195 dengan tingkat signifikansi 0,253>0,05. Maka hasil ini menyatakan organizational culture tidak berpengaruh terhadap motivasi. Oleh karena itu hipotesis kesatu dalam penelitian ini ditolak.

2) Hubungan antara Servant leadership dan Motivasi

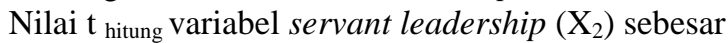
3,588 $>\mathrm{t}_{\text {tabel }}$ 2,0195 dengan tingkat signifikansi $0,001<0,05$. Maka hasil ini menyatakan servant leadership berpengaruh terhadap motivasi, dan hipotesis kedua dalam penelitian ini diterima.

3) Hubungan antara Non-physical work environment dan Motivasi

Nilai $\mathrm{t}_{\text {hitung variabel non-physical work environment }}$ $\left(\mathrm{X}_{3}\right)$ sebesar 2,221 $>\mathrm{t}$ tabel 2,0195 dengan tingkat signifikansi $0,032<0,05$. Maka hasil ini menyatakan non-physical work environment berpengaruh terhadap motivasi, dan hipotesis ketiga dalam penelitian ini diterima.

b. Pengujian Model 2

$\mathrm{t}$ tabel dalam pengujian model 1 yaitu, $\mathrm{df}=44-4=$ 40 nilai $t_{\text {tabel }}$ sebesar 2,0211 .

Tabel 15. Hasil Uji Hipotesis Sub Struktural I

\section{Unstandardi Standardiz \\ zed \\ ed \\ Coefficients Coefficients}

\begin{tabular}{|c|c|c|c|c|c|}
\hline Model & $\underline{\mathbf{B}}$ & $\begin{array}{l}\text { Std. } \\
\text { Error }\end{array}$ & Beta & $\underline{\mathbf{t}}$ & Sig \\
\hline 1. (constant) & $4 . \overline{253}$ & 3.094 & & $1 . \overline{374}$ & $.1 \overline{7} 7$ \\
\hline $\begin{array}{l}\text { Jrganizationa } \\
\text { I Culture }\end{array}$ & .246 & .116 & .268 & 2.119 & .041 \\
\hline $\begin{array}{c}\text { Servant } \\
\text { Leadership }\end{array}$ & .063 & .177 & .047 & .358 & .723 \\
\hline $\begin{array}{l}\text { Nonphysical } \\
\text { Work } \\
\text { Environment }\end{array}$ & .173 & .241 & .087 & .717 & .477 \\
\hline Motivasi & .781 & .167 & .589 & 4.672 & .000 \\
\hline
\end{tabular}

Sumber: Data primer diolah, 2019 
1) Hubungan antara Organizational culture dan Job performance

Nilai t hitung variabel organizational culture $\left(\mathrm{X}_{1}\right)$ sebesar 2,119>t tabel 2,0211 dengan tingkat signifikansi $0,041<0,05$. Maka hasil ini menyatakan organizational culture berpengaruh terhadap job performance, dan hipotesis keempat dalam penelitian ini diterima.

2) Hubungan antara Servant leadership dan Job performance

Nilai $\mathrm{t}$ hitung variabel servant leadership $\left(\mathrm{X}_{2}\right)$ sebesar $0,258<\mathrm{t}_{\text {tabel }} 2,0211$ dengan tingkat signifikansi 0,723

$>0,05$. Maka hasil ini menyatakan servant leadership tidak berpengaruh terhadap job performance, dan hipotesis kelima dalam penelitian ini ditolak.

3) Hubungan antara Non-physical work environment dan Job performance

Nilai $\mathrm{t}$ hitung variabel non-physical work environment $\left(\mathrm{X}_{3}\right)$ sebesar $0,717<\mathrm{t}$ tabel 2,0211 dengan tingkat signifikansi 0,477>0,05. Maka hasil ini menyatakan non-physical work environment tidak berpengaruh terhadap job performance, dan hipotesis keenam dalam penelitian ini ditolak.

4) Hubungan antara Motivasi dan Job performance Nilai $\mathrm{t}$ hitung variabel motivasi $\left(\mathrm{Y}_{1}\right)$ sebesar 4,672>t tabel 2,0211 dengan tingkat signifikansi $0,000<0,05$. Maka hasil ini menyatakan motivasi berpengaruh terhadap job performance, dan hipotesis ketujuh dalam penelitian ini diterima.

\section{Koefisien Determinasi}

Koefisien determinasi $\left(\mathrm{R}^{2}\right)$ adalah untuk mengukur sejauh kemampuan model dalam menerangkan variasi variabel dependen. Besarnya koefisien determinasi mendekati angka 0 sampai 1, besar koefisien determinasi mendekati angka 1 maka semakin besar pengaruh variabel independen terhadap variabel dependen. Hasil perhitungan dalam model summary sebagai berikut:

Tabel 16. Koefisien Determinasi Sub Struktural I

\begin{tabular}{|c|c|c|c|c|}
\hline \multicolumn{5}{|c|}{ Model Summaryb } \\
\hline Model & $\mathbf{R}$ & $\begin{array}{c}\text { R } \\
\text { Square }\end{array}$ & $\begin{array}{l}\text { Adjusted } \\
\text { R Square }\end{array}$ & $\begin{array}{l}\text { Std. Error of } \\
\text { the Estimate }\end{array}$ \\
\hline 1 & $.601^{a}$ & .361 & .313 & 1.343 \\
\hline
\end{tabular}

a. Predictors: (Constant), Nonphysical Work

Environment, Servant Leadership, Organizational

Culture

b. Dependent Variable: Motivasi

Sumber: Data primer diolah, 2019

Berdasarkan hasil analisis diperoleh nilai koefisien determinasi $\left(\mathrm{R}^{2}\right)$ sebesar 0,313 Atau $31,3 \%$. Hal ini menunjukkan bahwa nilai sebesar $31,3 \%$ variabel bebas yang terdiri dari organizational culture, servant leadership dan non-physical work environment dapat menjelaskan pengaruhnya terhadap variabel terikat yaitu variabel motivasi. Sedangkan sisanya $68,7 \%$ dipengaruhi variabel lainnya.
Tabel 17. Koefisien Determinasi Sub Struktural II Model Summary ${ }^{b}$

\begin{tabular}{|c|c|c|c|c|}
\hline Model & $\mathbf{R}$ & $\begin{array}{c}\mathbf{R} \\
\text { Square }\end{array}$ & $\begin{array}{l}\text { Adjusted } \\
\text { R Square }\end{array}$ & $\begin{array}{l}\text { Std. Error of } \\
\text { the Estimate }\end{array}$ \\
\hline 1 & $.777^{\mathrm{a}}$ & .603 & .563 & 1.421 \\
\hline
\end{tabular}

a. Predictors: (Constant), Motivasi, Organizational

Culture, Nonphysical Work Environment, Servant

Leadership,

b. Dependent Variable: Job Performance

Sumber: Data primer diolah, 2019

Berdasarkan hasil analisis diperoleh nilai koefisien determinasi $\left(\mathrm{R}^{2}\right)$ sebesar 0,563 Atau 56,3\%. Hal ini menunjukkan bahwa nilai sebesar $56,3 \%$ variabel bebas yang terdiri dari organizational culture, servant leadership, non-physical work environment dan motivasi dapat menjelaskan pengaruhnya terhadap variabel terikat yaitu variabel job performance. Sedangkan sisanya 43,7\% dipengaruhi variabel lainnya.

Hasil analisis model 1 dan model 2 menjelaskan bahwa dengan besarnya nilai dari variabel bebas mempengaruhi variabel terikat atau dapat dikatakan variabel motivasi dan job performance menjadi lebih tinggi karena faktor variabel bebas tersebut.

\section{Analisis Korelasi}

Penelitian ini akan menganalisis korelasi antar variabel organizational culture, servant leadership, non- physical work environment dan motivasi dengan hasil perhitungan sebagai berikut:

Tabel 18. Analisis Korelasi

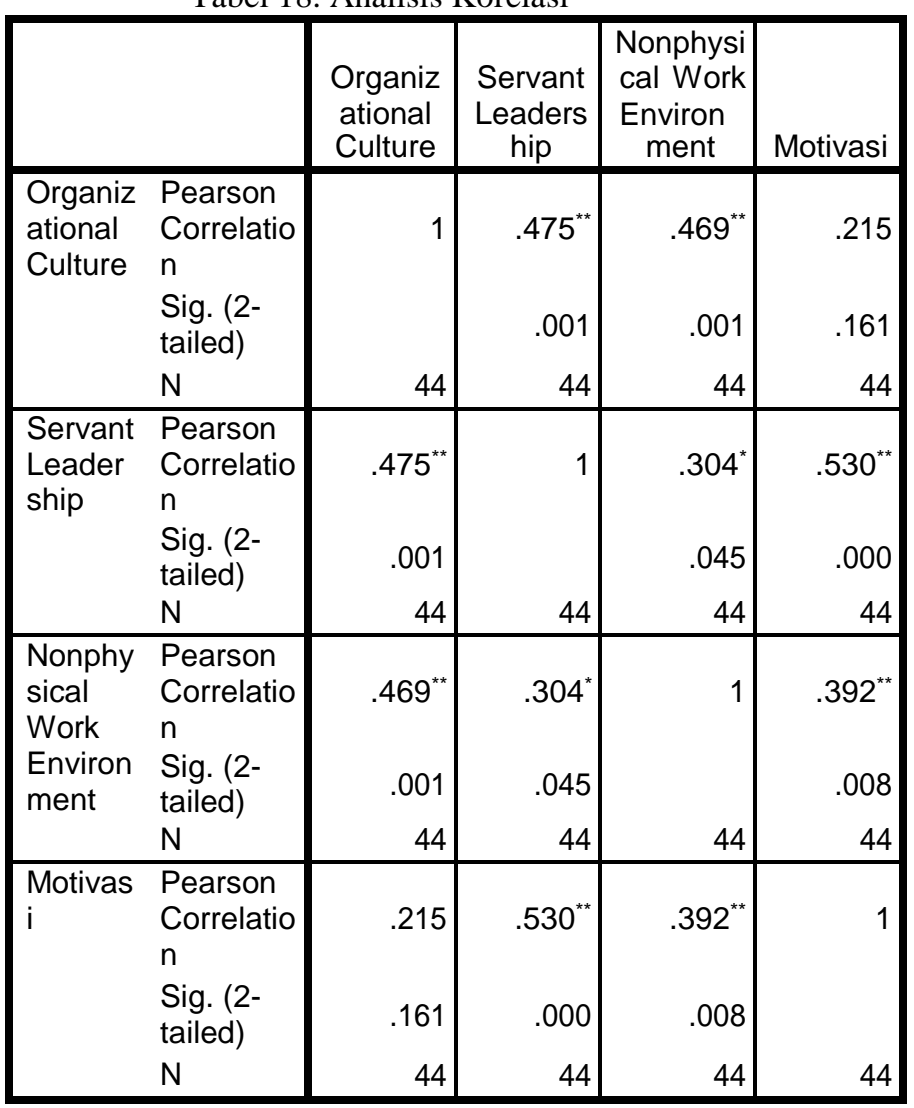

**. Correlation is significant at the 0.01 level (2-tailed).

* . Correlation is significant at the 0.05 level (2-tailed).

Sumber: Data prime diolah, 2019 
Korelasi antara variabel organizational culture, servant leadership, non-physical work environment dan motivasi. Berdasarkan tabel 18 dapat diperoleh hasil sebagai berikut:

1. Korelasi antara Organizational culture dan Servant leadership

Berdasarkan perhitungan diperoleh angka korelasi sebesar 0,475, angka korelasi tersebut memiliki arti hubungan antara variabel organizational culture dan servant leadership cukup dan searah (karena hasilnya positif). Searah maksudnya ialah jika organizational culture tinggi maka servant leadership juga tinggi. Korelasi dua variabel bersifat signifikan karena angka signifikansi sebesar $0,001<0,05$.

2. Korelasi antara Organizational culture dan Nonphysical work environment

Berdasarkan perhitungan diperoleh angka korelasi sebesar 0,469 angka korelasi tersebut memiliki arti hubungan antara variabel organizational culture dan non-physical work environment cukup dan searah (karena hasilnya positif). Searah maksudnya ialah jika organizational culture tinggi maka non-pysical work environment juga tinggi. Korelasi dua variabel bersifat signifikan karena angka signifikansi sebesar 0,001 < 0,05 .

3. Korelasi antara Organizational culture dan Motivasi

Berdasarkan perhitungan diperoleh angka korelasi sebesar 0,215 angka korelasi tersebut memiliki arti hubungan antara variabel organizational culture dan motivasi lemah. Korelasi dua variabel tidak signifikan karena angka signifikansi sebesar 0,161 > 0,05.

4. Korelasi antara Servant leadership dan Non-physical work environment

Berdasarkan perhitungan diperoleh angka korelasi sebesar 0,304 angka korelasi tersebut memiliki arti hubungan antara variabel servant leadership dan nonphysical work environment cukup dan searah (karena hasilnya positif). Searah maksudnya ialah jika servant leadership tinggi maka non-physical work environment juga tinggi. Korelasi dua variabel bersifat signifikan karena angka signifikansi sebesar 0,045 < 0,05 .

5. Korelasi antara Servant leadership dan motivasi

Berdasarkan perhitungan diperoleh angka korelasi sebesar 0,530 angka korelasi tersebut memiliki arti hubungan antara variabel servant leadership dan motivasi kuat dan searah (karena hasilnya positif). Searah maksudnya ialah jika servant leadership tinggi maka motivasi juga tinggi. Korelasi dua variabel bersifat signifikan karena angka signifikansi sebesar $0,000<0,05$.

6. Korelasi antara Non-physical work environment dan motivasi

Berdasarkan perhitungan diperoleh angka korelasi sebesar 0,392 angka korelasi tersebut memiliki arti hubungan antara variabel non-physical work environment dan motivasi cukup dan searah (karena hasilnya positif). Searah maksudnya ialah jika nonphysical work environment tinggi maka motivasi juga tinggi. Korelasi dua variabel bersifat signifikan karena angka signifikansi sebesar $0,008<0,05$.

\section{Analisis Jalur}

Analisis jalur (path analysis) menurut sugiyono (2010: 297) merupakan pengembangan dari analisis regresi, sehingga analisis regresi dapat dikatakan sebagai bentuk khusus dari analisis jalur. Tujuan analisis ini adalah menerangkan akibat langsung (direct effect) dan tidak langsung (indirect effect) seperangkat variabel, sebagai variabel penyebab, terhadap variabel lainnya yang merupakan variabel akibat. Persamaan substruktural terdiri dari 2 persamaan $\mathrm{X}_{1}, \mathrm{X}_{2}$ dan $\mathrm{X}_{3}$ adalah variabel independen, $\mathrm{Y}_{1}$ dan $\mathrm{Y}_{2}$ adalah variabel dependen. Sehingga diperoleh persamaan struktural 1 dan struktural 2 sebagai berikut:

$\mathrm{Y}_{1}=\mathrm{PY}_{1} \mathrm{X}_{1}+\mathrm{PY}_{1} \mathrm{X}_{2}+\mathrm{PY}_{1} \mathrm{X}_{3}+€_{1} \quad$ Persamaan Struktural I $\mathrm{Y}_{2}=\mathrm{PY}_{2} \mathrm{X}_{1}+\mathrm{PY}_{2} \mathrm{X}_{2}+\mathrm{PY}_{2} \mathrm{X}_{3}+\mathrm{PY}_{2} \mathrm{Y}_{1}+€_{1} \ldots \ldots \ldots \ldots \ldots . .$. Persamaan Struktural II

Dimana:

$\mathrm{Y}_{1} \quad=$ Motivasi

$\mathrm{X}_{1} \quad=$ Organizational culture

$\mathrm{X}_{2} \quad=$ Servant Leadership

$\mathrm{X}_{3} \quad=$ Non-physical Work Environment

$€_{1} \quad=$ Error

Berdasarkan hasil output SPSS Pada Tabel IV-19 diperoleh koefisien regresi, dimana koefisien regresinya dapat disusun sebagai berikut:

a. Sub Struktural I

$\mathrm{Y}_{1}=-0,181 \mathrm{X}_{1}+0,518 \mathrm{X}_{2}+0,320 \mathrm{X}_{3}+€_{1}$

Dimana $€_{1}=\sqrt{1-R^{2}}=\sqrt{1-0,313}=\sqrt{0,687}=$ 0,829

1) Koefisien regresi variabel organizational culture $\left(\mathrm{X}_{1}\right)=-0,181$

Koefisien regresi untuk $\mathrm{X}_{1}$ sebesar -0,181 artinya setiap penambahan 1 satuan skala likert pada variabel organizational culture $\left(\mathrm{X}_{1}\right)$ maka akan mengurangi motivasi sebesar $-0,181$.

2) Koefisien regresi variabel servant leadership $\left(\mathrm{X}_{2}\right)=0,518$

Koefisien regresi untuk $\mathrm{X}_{2}$ sebesar 0,518 artinya setiap penambahan 1 satuan skala likert pada variabel servant leadership $\left(\mathrm{X}_{2}\right)$ maka akan menambah motivasi sebesar 0,518.

3) Koefisien regresi variabel non-physical work environment $\left(\mathrm{X}_{3}\right)=0,320$

Koefisien regresi untuk $\mathrm{X}_{3}$ sebesar 0,320 artinya setiap penambahan 1 satuan skala likert pada variabel non-physical work environment $\left(\mathrm{X}_{3}\right)$ maka akan menambah motivasi sebesar 0,320.

4) $\operatorname{Eror}\left(€_{1}\right)$

Eror $\left(€_{1}\right)$ sebesar 0,829 menunjukkan motivasi yang tidak dapat dijelaskan oleh variabel organizational culture, servant leadership dan non-physical work environment diabaikan atau sama dengan nol.

b. Sub Struktural II

$\mathrm{Y}_{2}=\mathrm{PY}_{2} \mathrm{X}_{1}+\mathrm{PY}_{2} \mathrm{X}_{2}+\mathrm{PY}_{2} \mathrm{X}_{3}+\mathrm{PY}_{2} \mathrm{Y}_{1}+€_{1}$

$\mathrm{Y}_{2}=0,268 \mathrm{X}_{1}+0,047 \mathrm{X}_{2}+0,087 \mathrm{X}_{3}+0,589 \mathrm{Y}_{1}+€_{2}$

$$
\text { Dimana } €_{2}=\sqrt{1-R^{2}}=\sqrt{1-0,563}
$$


1) Koefisien regresi variabel organizational culture $\left(\mathrm{X}_{1}\right)=0,268$

Koefisien regresi untuk $\mathrm{X}_{1}$ sebesar 0,268 artinya setiap penambahan 1 satuan skala likert pada variabel organizational culture $\left(\mathrm{X}_{1}\right)$ maka akan menambah job performance sebesar 0,268.

2) Koefisien regresi variabel servant leadership $\left(\mathrm{X}_{2}\right)=0,047$

Koefisien regresi untuk $\mathrm{X}_{2}$ sebesar 0,047 artinya setiap penambahan 1 satuan skala likert pada variabel servant leadership $\left(\mathrm{X}_{2}\right)$ maka akan menambah job performance sebesar 0,047.

3) Koefisien regresi variabel non-physical work environment $\left(\mathrm{X}_{3}\right)=0,087$

Koefisien regresi untuk $X_{3}$ sebesar 0,087 artinya setiap penambahan 1 satuan skala likert pada variabel non-physical work environment $\left(\mathrm{X}_{3}\right)$ maka akan menambah job performance sebesar 0,087 .

4) Koefisien regresi variabel Motivasi $\left(Y_{1}\right)=0,589$ Koefisien regresi untuk $\mathrm{Y}_{1}$ sebesar 0,589 artinya setiap penambahan 1 satuan skala likert pada variabel motivasi $\left(\mathrm{Y}_{1}\right)$ maka akan menambah job performance sebesar 0,589 .

5) Eror $\left(€_{2}\right)=0,661$

Eror $\left(€_{2}\right)$ sebesar 0,661 menunjukkan job performance yang tidak dapat dijelaskan oleh variabel organizational culture, servant leadership, non-physical work environment dan motivasi diabaikan atau sama dengan nol.

\section{Diagram Jalur}

Gambar 5. Diagram jalur

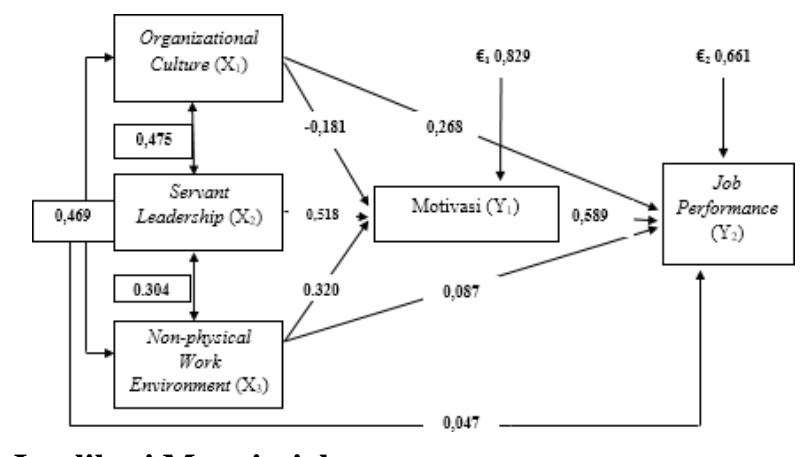

Implikasi Manajerial

Penelitian ini bertujuan untuk mengetahui seberapa besar pengaruh organizational culture, servant leadership dan non-physical work environment terhadap motivasi dan job performance pegawai Badan Pusat Statistik Kabupaten Kebumen. Implikasi kebijakan yang disarankan dalam penelitian ini adalah sebagai berikut:

1. Pengaruh Organizational Culture terhadap Motivasi

Hasil penelitian menunjukkan tidak adanya pengaruh organizational culture terhadap motivasi, diketahui dari nilai t variabel organizational culture sebesar $-1.161<\mathrm{t}$ tabel 2,0195 dengan sinifikansi sebesar 0,253>0,05 sehingga $\mathrm{H}_{0}$ diterima dan $\mathrm{H}_{1}$ ditolak. Berdasarkan hasil tersebut bearti tidak adanya hubungan linear antara organizational culture dan motivasi. Besarnya pengaruh organizational culture terhadap motivasi sebesar $-0,181$ atau $-18,1 \%$.
Organizational culture pada Badan Pusat Statistik Kabupaten Kebumen belum dapat memotivasi pegawai secara langsung.

Hasil ini tidak selaras dengan hasil penelitian Jamaluddin, dkk (2017) yang hasilnya ialah organizational culture berpengaruh terhadap motivasi kerja pegawai. Pegawai Badan Pusat Statistik Kabupaten Kebumen tidak termotivasi dengan ditingkatkannya penerapan organizational culture, motivasi pegawai terbangun oleh faktor yanglain.

2. Pengaruh Servant Leadership terhadap Motivasi

Hasil penelitian menunjukkan bahwa adanya pengaruh servant leadership terhadap motivasi, dengan nilai $\mathrm{t}$ variabel servant leadership sebesar $3,588>\mathrm{t}$ tabel 2,0195 dan tingkat signifikansi 0,001. Berdasarkan hasil tersebut dinyatakan $\mathrm{H}_{0}$ ditolak dan $\mathrm{H}_{1}$ diterima. Hasil tersebut menunjukkan adanya hubungan linear antara servant leadership dan motivasi. Besarnya pengaruh servant leadership terhadap motivasi sebesar 0,518 atau 51,8\%. Hasil tersebut sudah menunjukkan bahwa semakin tinggi servant leadership yang diterapkan oleh pimpinan maka dapat memotivasi secara langsung pegawai Badan Pusat Statistik Kabupaten Kebumen.

Hasil penelitian ini selaras dengan hasil penelitian Aprilliansyah, Astuti dan Sulistyo (2018), bahwa servant leadership berpengaruh secara positif dan signifikan terhadap motivasi kerja. Pimpinan Badan Pusat Statistik Kabupaten Kebumen dengan mengakui kontribusi pegawai, maka pegawai akan berusaha untuk menyelesaikan persoalan yang muncul.

3. Pengaruh Non-physical Work Environment terhadap Motivasi

Hasil penelitian menunjukkan bahwa adanya pengaruh non-physical work environment terhadap motivasi, dengan nilai t variabel non-physical work environment sebesar 2,221 > t tabel 2,0195 dan tingkat signifikansi 0,032. Berdasarkan hasil tersebut dinyatakan $\mathrm{H}_{0}$ ditolak dan $\mathrm{H}_{1}$ diterima. Hasil tersebut menunjukkan adanya hubungan linear antara nonphysical work environment dan motivasi. Besarnya pengaruh non-physical work environment terhadap motivasi sebesar 0,320 atau $32 \%$. Hal ini berarti semakin baik non-physical work environment maka akan semakin tinggi motivasi pada pegawai. Hubungan kerja antara sesama rekan kerja dan dengan pemimpin pada BPS Kabupaten Kebumen sudah baik, sehingga hal tersebut dapat mempengaruhi motivasi pegawai dalam mengerjakan tugasnya masingmasing.

Hasil tersebut sesuai dengan hasil penelitian terdahulu yang dilakukan oleh Setyadi, Utami dan Tjahtjono (2015), dengan hasil bahwa lingkungan kerja non-fisik berpengaruh terhadap motivasi kerja. Pegawai Badan Pusat Statistik saling membantu rekan kerja saat membutuhkan bantuan, sehingga pegawai dapat bekerja sendiri ataupun secara kelompok.

4. Pengaruh Organizational Culture terhadap Job Performance 
Hasil penelitian menunjukkan bahwa adanya pengaruh organizational culture terhadap job performance, dengan nilai t variabel organizational culture sebesar 2,119>t tabel 2,0211 dan tingkat signifikansi 0,041. Berdasarkan hasil tersebut dinyatakan $\mathrm{H}_{0}$ ditolak dan $\mathrm{H}_{1}$ diterima. Hasil tersebut menunjukkan adanya hubungan linear antara organizational culture dan job performance. Besarnya pengaruh organizational culture terhadap job performance sebesar 0,268 atau $26,8 \%$. Hal ini berarti bahwa organizational culture pada BPS Kabupaten Kebumen dapat berpengaruh secara langsung terhadap job performance yang dimiliki pegawai. Semakin baik organizational culture pada BPS Kabupaten Kebumen, maka akan meningkatkan job performance pegawai.

Hasil tersebut selaras dengan penelitian terdahulu yang dilakukan oleh Haqq (2016) yaitu bahwa budaya organisasi berpengaruh terhadap kinerja pegawai. Pegawai merasa dituntut untuk menyelesaikan pekerjaan dengan tepat dan cermat, sehingga pegawai akan memiliki job performance yang berkualitas.

5. Pengaruh Servant Leadership terhadap Job Performance

Hasil penelitian menunjukkan tidak adanya pengaruh servant leadership terhadap job performance, diketahui dari nilai $\mathrm{t}$ variabel servant leadership sebesar $0,358<\mathrm{t}$ tabel 2,0211 dengan sinifikansi sebesar 0,723>0,05 sehingga $\mathrm{H}_{0}$ diterima dan $\mathrm{H}_{1}$ ditolak. Berdasarkan hasil tersebut berarti tidak adanya hubungan linear antara servant leadership dan job performance. Besarnya pengaruh servant leadership terhadap job performance sebesar 0,047 atau $4,7 \%$. Hal ini berarti kepemimpinan servant leadership BPS kabupaten Kebumen tidak berpengaruh secara langsung terhadap job performance pegawai.

Hasil tersebut tidak sesuai dengan hasil penelitian Aji dan Palupiningdyah (2016) bahwa servant leadership berpengaruh terhadap kinerja pegawai. Pimpinan pada Badan Pusat Statistik Kabupaten Kebumen yang memiliki visi untuk masa depan pegawai tidak mempengaruhi kualitas dan kuantitas job performance pegawai.

6. Pengaruh Non-physical Work Environment terhadap Job Performance

Hasil penelitian menunjukkan tidak adanya pengaruh non-physical work environment terhadap job performance, diketahui dari nilai t variabel nonphysical work environment sebesar $0,717<\mathrm{t}$ tabel 2,0211 dengan sinifikansi sebesar 0,477>0,05 sehingga $\mathrm{H}_{0}$ diterima dan $\mathrm{H}_{1}$ ditolak. Berdasarkan hasil tersebut berarti tidak adanya hubungan linear antara non-physical work environment dan job performance. Besarnya pengaruh non-physical work environment terhadap job performance sebesar 0,087 atau $8,7 \%$. Hal ini berarti lingkungan kerja non-fisik pada BPS Kabupaten Kebumen tidak berpengaruh terhadap job performance pegawai.
Hasil tersebut berarti tidak selaras dengan hasil penelitian Widianingrum dan Djastuti (2016) bahwa non-physical work environment berpengaruh terhadap job performance pegawai. Non-physical work environment yang terjalin dalam organisasi seperti rekan kerja yang saling membantu tidak mempengaruhi kualitas atau kuantitas pekerjaan pegawai.

7. Pengaruh Motivasi terhadap Job Performance

Hasil penelitian menunjukkan bahwa adanya pengaruh motivasi terhadap job performance, dengan nilai $\mathrm{t}$ variabel motivasi sebesar 4,672 $>\mathrm{t}$ tabel 2,0211 dan tingkat signifikansi 0,000. Berdasarkan hasil tersebut dinyatakan $\mathrm{H}_{0}$ ditolak dan $\mathrm{H}_{1}$ diterima. Hasil tersebut menunjukkan adanya hubungan linear antara motivasi dan job performance. Besarnya pengaruh motivasi terhadap job performance sebesar 0,589 atau $58,9 \%$. Hal ini berarti pegawai dengan motivasi yang baik, akan berpengaruh secara signifikan terhadap peningkatakn kinerja pegawai Badan Pusat Statistik Kabupaten Kebumen. Pegawai BPS Kebumen sudah memiliki motivasi kerja yang baik sehingga hal tersebut dapat mempengaruhi secara signifikan kinerja pegawai.

Hasil penelitian ini sesuai dengan hasil penelitian terdahulu yang dilakukan oleh Saputri, Fudholi, dan Sumarni (2014), hasil penelitian menunjukkan bahwa motivasi berpengaruh terhadap job performance. Pegawai Badan Pusat Statistik Kabupaten Kebumen merasa harus bertanggung jawab pada setiap tugas yang diberikan, sehingga pegawai menyelesaikan jumlah hasil kerja seperti yang telah diberikan oleh organisasi.

\section{PENUTUP}

\section{Kesimpulan}

Berdasarkan hasil penelitian yang dilakukan pada pegawai Badan Pusat Statistik Kabupaten Kebumen, maka dapat disimpulkan sebagai berikut:

1. Organizational culture pada Badan Pusat Statistik Kabupaten Kebumen tidak memiliki pengaruh terhadap motivasi kerja pegawai. Hasil tersebut berarti semakin tinggi atau rendahnya organizational culture tidak mempengaruhi motivasi kerja pegawai Badan Pusat Statistik Kabupaten Kebumen.

2. Servant leadership memiliki pengaruh yang positif dan signifikan terhadap motivasi kerja pegawai Badan Pusat Statistik Kabupaten Kebumen. Artinya apabila semakin baik servant leadership maka akan meningkatkan motivasi kerja pegawai.

3. Non-physical work environment memiliki pengaruh yang positif dan signifikan terhadap motivasi kerja pegawai Badan Pusat Statistik Kabupaten Kebumen. Artinya apabila semakin baik non-physical work environment maka akan meningkatkan motivasi kerja pegawai.

4. Organizational culture memiliki pengaruh yang positif dan signifikan terhadap Job Performance pegawai Badan Pusat Statistik Kabupaten Kebumen. Artinya apabila semakin baik organizational culture 
yang diterapkan, maka akan meningkatkan job performance pegawai.

5. Servant leadership pada Badan Pusat Statistik Kabupaten Kebumen tidak memiliki pengaruh terhadap job performance. Hasil tersebut berarti semakin tinggi atau rendahnya servant leadership tidak mempengaruhi job performance secara langsung pada pegawai Badan Pusat Statistik Kabupaten Kebumen.

6. Non-physical work environment pada Badan Pusat Statistik Kabupaten Kebumen tidak memiliki pepengaruh terhadap job performance pegawai. Hasil tersebut berarti semakin tinggi atau rendahnya non-physical work environment tidak mempengaruhi job performance secara langsung pada pegawai Badan Pusat Statistik Kabupaten Kebumen.

7. Motivasi memiliki pengaruh positif dan signifikan terhadap job performance pegawai Badan Pusat Statistik Kabupaten Kebumen. Artinya apabila semakin baik motivasi kerja yang dimiliki oleh seorang pegawai, maka akan meningkatkan job performance pegawai tersebut.

8. Variabel yang paling dominan berpengaruh terhadap motivasi pegawai Badan Pusat Statistik Kabupaten Kebumen adalah servant leadership karena mempunyai nilai koefisien terbesar jika dibandingkan dengan variabel lain dengan nilai standardized coefficient B sebesar 0,518.

9. Variabel yang paling dominan berpengaruh terhadap job performance pegawai Badan Pusat Statistik Kabupaten Kebumen adalah Motivasi karena mempunyai nilai koefisien terbesar jika dibandingkan dengan variabel lain dengan nilai standardized coefficient B sebesar 0,589.

\section{Saran}

Berdasarkan hasil penelitian, dapat dikemukakan beberapa saran yang diharapkan dapat memberikan manfaat bagi organisasi maupun bagi pihak-pihak lain. Adapun saran yang diberikan antara lain:

1. Pihak manajemen dalam rangka meningkatkan job performance pegawai Badan Pusat Statistik Kabupaten Kebumen sebaiknya memaksimalkan penerapan organizational culture yang lebih baik lagi supaya seluruh anggota organisasi dapat berjalan selaras dengan budaya yang telah diciptakan. Peningkatan tersebut seperti lebih mengarahkan pegawai untuk merasa tidak puas dengan satu tugas, sehingga pegawai akan bertanggung jawab dalam mengerjakan tugas-tugas. Organisasi dapat menekankan pentingnya koordinasi dengan rekan kerja dan pimpinan dalam melaksanakan pekerjaan dan memberikan kenyamanan bagi setiap pegawai, sehingga dengan hal tersebut diharapkan pegawai akan memiliki job performance yang berkualitas.

2. Pihak manajemen Badan Pusat Statistik Kabupaten Kebumen dalam meningkatkan job performance pegawai sebaiknya mempertahankan dan meningkatkan beberapa hal dalam servant leadership sesuai dengan yang sudah diterapkan. Hal yang perlu ditingkatkan yaitu pimpinan lebih mendengarkan saran yang disampaikan oleh pegawai dan mengakui akan kontribusi dari setiap pegawai. Berdasarkan hal tersebut pegawai diharapkan akan lebih termotivasi dan akan meningkatkan job performance pegawai.

3. Pihak manajemen dalam rangka meningkatkan job performance pegawai, mempertahankan Non-pysical work environment yang sudah terjalin. Organisasi memberikan pekerjaan yang bersifat teamwork, sehingga diharapkan hubungan kerja satu pegawai dengan pegawai lain baik dan akan menciptakan pegawai yang mampu bekerja secara kelompok.

4. Pihak manajemen hendaknya memberikan motivasi pegawai dalam meningkatkan job performance pegawai. Seperti membuat program dimana pegawai akan merasa lebih bertanggung jawab dan berkemauan mengembangkan potensi dalam diri. Hal tersebut diharapkan mampu untuk pegawai mengerjakan pekerjaan secara individual maupun secara kelompok dengan baik, tepat, dan akurat sesuai dengan tujuan yang ditetapkan.

5. Bagi peneliti selanjutnya diharapkan mencari faktor lain yang memiliki pengaruh besar terhadap variabel dependen dalam penelitian ini. Dikarenakan dilihat dari nilai $\mathrm{R}^{2}$ motivasi sebesar 0,313 atau $31,3 \%$ dan untuk nilai $\mathrm{R}^{2}$ job performance sebesar 0,563 atau $56,3 \%$. Sehingga masih banyak terdapat kemungkinan variabel-variabel yang diduga memiliki pengaruh yang besar terhadap motivasi dan job performance, seperti Kompetensi dan Profesional.

\section{Daftar pustaka}

Aji, Muhammad dan Palupiningdyah. 2016. "Pengaruh Servant Leadership terhadap Kinerja Karyawan dengan Burnout sebagai Variabel Intervening". Management Analysis Journal. Vol.5, No. 3.

Apriliansyah, Andre, Endang Siti Astuti dan Muhammad Cahyo Widyo Sulistyo. 2018. "Analisis Kompensasi dan Servant Leadership Pengaruhnya terhadap Motivasi Kerja dan Kinerja Karyawan". Jurnal Administrasi Bisnis Universitas Brawijaya. Vol. 61, No. 3 (Agustus).

BPS Indonesia. Informasi Umum. https://www.bps.go.id/ (diakses 13 Oktober 2018).

Dennis, R. 2004. Development of the Servant Leadership Assesment Instrumen. Leadership \& Organization Development Journal.

Ghozali, Imam. 2006. Aplikasi Analisis Multivariate dengan Program SPSS. Semarang: UNDIP.

2009. Aplikasi Analisis Multivariate dengan Program SPSS. Semarang: UNDIP.

Gomes, Cardoso Faustino. 2010. Manajemen Sumber Daya Manusia. Yogyakarta: Andi.

Haqq, Najmy. 2016. "Pengaruh Budaya Organisasi terhadap Kinerja Karyawan melalui Motivasi sebagai Variabel (Studi pada PT. Rahmat Jaya Perkasa, Sidoarjo". Jurnal Bisnis dan Manajemen. Vol. 9, No.1 (Oktober).

Hasibuan, Malayu. 2002. Manajemen Sumber Daya Manusia. Jakarta: Bumi Aksara. 
2003. Organisasi dan Motivasi Dasar Peningkatan Produktifitas. Jakarta: Bumi Aksara.

Jamaluddin, et al. 2017. "Pengaruh Budaya Organisasi terhadap Kinerja Pegawai pada Dinas Pendidikan Provinsi Sulawesi". Jurnal Ad'ministrare Universitas Negeri Makassar. Vol. 4. No. 1, 2017.

Mangkunegara, AA Anwar Prabu. 2011. Manajemen Sumber Daya Manusia Perusahaan. Bandung: Remaja Rosdakarya.

Robbins, Stephen P. 2006. Organizational Behaviour, Concept, Controversie, Application. Seventh Edition. Prentice Hall Inc. New South Wales.

Saputri, Laras Tri, Achmad Fudholi, Sumarni. 2014. "Pengaruh Motivasi Kerja dan Budaya Organisasi terhadap Kinerja Karyawan”. Jurnal Manajemen dan Pelayanan Farmasi. Vol. 4, No.1 (Maret).

Sedarmayanti. 2009. Sumber Daya Manusia dan Produktifitas Kerja. Bandung: Bandar Maju.

Setyadi, Benny, Hamidah Hayati dan Gunawan Eko Nurtjahjono. 2015. "Pengaruh Lingkungan Kerja Fisik dan Non Fisik terhadap Motivasi Kerja dan Kinerja Karyawan (Studi pada Karyawan PT. Bank BRI, Tbk. Cabang Bogor)". Jurnal Administrasi Bisnis. Vol. 21, No. 1 (April).

Sugiyono. 2010. Metode Penelitian Kuantitatif, Kualitatif dan $R \& D$. Bandung: Alfabeta.

Trompenaars, Fons dan Voerman, Ed. 2010. Servant Leadership Across Culture: Harnessing the strength of the world's most powerful leadership philosophy. New York: Infinite Ideas Limited.

Veithzal, Rivai. 2005. Manajemen Sumber Daya Manusia. Jakarta: Raja Grafindo Persada.

Widianingrum, Ayu dan Indi Djastuti. 2016. "Pengaruh Lingkungan Kerja Fisik, Lingkungan Kerja Nonfisik dan Stres Kerja terhadap Kinerja Karyawan". Diponegoro Journal of Management. Vol. 5, No.4, 1- 10. 